\title{
The Divergence of Democratic Policing: Reflection on Brazil and Argentina
}

\author{
Soniya Wazed ${ }^{1, *}$, Jinea Akhtar ${ }^{2}$ \\ ${ }^{1}$ Department of Sociology, Jagannath University, Bangladesh \\ ${ }^{2}$ School of Business \& Economics, United International University, Bangladesh \\ *Corresponding Author: soniya_du@yahoo.com,jinea_akhtar@yahoo.com
}

Copyright $(\mathcal{C} 2015$ by authors, all rights reserved. Authors agree that this article remains permanently open access under the terms of the Creative Commons Attribution License 4.0 International License

\begin{abstract}
This paper highlights the existing literature on the nature and problem of policing by investigating their obvious and not so obvious origins, their enabling culture, reforms, and the immense challenges encountered by those trying to shake up the status quo. By way of literature review, further investigates the intricacies and complexities of democratizing policing in Latin America: Brazil and Argentina, in light of the fact that their governance systems have transitioned from military rule to electoral democracy and have been in operation for over two decades. The paper also explores why the police reforms that were introduced and implemented are yet to yield the desired results. Police in democratic states have increasingly been questioned over their roles and responsibility in order to determine whether they are actually reducing crime or merely increasing the fear of crime. Throughout the articles reviewed, common themes of trust and improved collaboration with stakeholders emerge, giving directions to where possible solutions of the problems may lie.
\end{abstract}

Keywords Democracy, Policing, Police Reform

\section{Introduction}

To citizens of Latin America, crime, occupies an upper position in the list of social, economic, and political concerns. This scenario, results from increased violence and crime especially between the 1980's and 1990s when the rate of homicide grew with a margin of over forty percent [1]. This reality has strained the relationship between governments and citizens, media, police and international donors. The complex sense of public insecurity has further propelled the fear of crime to levels that supersede actual crime rates. In response to these feelings of insecurity among the public, states and their politicians have been forced to come out heavy-handedly on the subject of public safety to gain the confidence of the electorate. This has led to the police yielding more and more power over time in the name of strengthening law enforcement and increasing their ability to tackle crime.

From the 1990's, there has been an increase in reforms aimed at improving and bringing the functions of the police to a level that resonates with the expectations of society. These reforms have tried to shake up the status quo by making numerous recommendations ranging from altering the hierarchies of powers, introducing technological tools, making the police sensitive to human rights to dismantling the police force and building up anew. The factor of time plays a rather important role in the process of implementing the police reforms and some of the evidence points at the fact that more time is needed to cement the objectives of the reforms as the programs are unfinished albeit still in motion.

The purpose of this paper is to provide insight on what the policing situation looks like in Latin America, particularly in Argentina and Brazil, the efforts of democratization that have been poured in and the challenges faced in the process. This is with the aim of understanding what is holding back the policing institution, why the concerned states have not been able to overcome the hurdles faced by police reforms, and why public insecurity continues to escalate despite the reforms.

\section{Background and Methods}

The police are the state's primary legal enforcers and embodiment of the law, providing in principal protection, access to justice, and redress. Police actions to detect crime and bring perpetrators to the attention of the courts for punishment are critical to the effective functioning of any criminal justice system [2].

In order to demistify the idea of policing, Rawlings [3] insists first, on the separation of the history of policing from that of the police, before merging the two subjects into a single entity. In the $18^{\text {th }}$ Century deviance was difficult to define and address as it was perceived as a local problem, with different communities and authorities defining it and tackling it in varied ways. Communities and individuals played a direct and central role in policing. It was not until the crime panic of 1748 , that the idea of establishing an 
organized institution to proactively detect crime and regulate the poor became viable, eventually making social control an attainable notion.

Fieldings' definition of policing took away responsibilities of deviance control from the hands of the communities and placed them into the hands of the state, relegating the role of individuals and communities to that of observing and reporting deviance to the police. The argument was that the police force was by all means more knowledgeable, skilled and better suited to manage the situations [3]. The flaw in this school of thought is that the constant failure to meet the objective of crime control, does not lead to genuine introspection by the policing instution but rather blames external factors for impeding their efforts.

In 1979 the United Nations put together a "Code of Conduct for Law Enforcement Officials". Initiatives like this have multiplied in recent years, also under the sponsorship of Human Rights and other non-governmental organizations. Jones et al. [4]. draw seven criteria for the democratic governance of policing, such as "equity, delivery of service, responsiveness, distribution of power, information, redress, and participation". In 1997, Das [5] and Marenin [6] organized a seminar with police representatives from thirteen countries. They draw seven principles of democratic policing. Participants agreed that democratic policing should include respect for the "rule of law, accountability to the public, transparency of decision making, popular participation in policing, minimum use of force, creating an organization that facilitates learning of civil and human rights, and internal democracy in the organization" [5].

The identification of the principles of democratic policing is an important step but examining the extent to which these values are visible within policing policies and practices is one potentially important approach to assessing the democratic nature of policing. Eventually one can argue that this does not cover the whole breadth of actors and actions that constitute the wider sense of policing, and thus Hinton and Newburn [2] state that the police role in any democracy is bound to be contentious and imperfectly aligned with the broader procedures, objectives, and practices of a democratic polity. Therefore, we need to identify the major domestic challenges to achieving democratic forms of accountability over the police.

This paper investigates the issue of policing and democracy primarily through literature review, analyzing both the qualitative and quantitative data. The articles reviewed in this paper were subjected to a selection criteria and the study utilized a few maps that affirmed the coorelation between incidents of narcotics and districts with black populations. The case studies used helped to single out jurisdictions that show the precise circumstances under which selective drug law enforcement takes place. Detailed narratives of kidnapping incidences were used to demystify the conflict that exists between the civil police and military police: the two arms of the police. To successfully carry out a comparative analysis, this study employed 'cities' as a critical criteria, measured by demographic profiles of residents, population densities, growth trends and socio-geographic factors make fair comparisons with other urban areas such as: New York, Cleveland and Seattle. This exercise emphasized the fact that local policing differs substantially in every city and responds differently to 'problem areas'. Drawing similiarities between States in Latin America focusing on the two most powerful nations: Brazil and Argentina, with respect to their shared history of repressive rule under the military, this paper was able to add to the comparative analysis. Through interviews and narratives from police officers across the board the paper was able to re-examine the power held by the police.

Before discusing the existung literatures on policing and democracy in the global South, this paper highlights a brief discussion of the organizations of policing in Argentina and Brazil.

\section{Argentinean Police}

Argentinean police forces were reorganized during the 19th century after centralized and hierarchical, French and Prussian, models of police. During the last third of that century, amidst the explosive growth of the Argentinean society, the police developed a tradition of repressive and violent treatment of activists and poor people. There are four national public security forces in Argentina, such as Argentinean Federal Police (PFA), National Gendarmerie, Argentinean Coast Guards and Airport Security Police. As Argentina is organized as a federal state, each of the 23 provinces has one Police organization and there is no separate city-level Police. Each city's Police is the same as the Provincial Police, with very few exceptions in the areas protected by national forces like ports or highly violent neighborhoods. Although the federal PFA has an investigative role in all the Argentinean territory and it is also the street level Police in the City of Buenos Aires. Interestingly, the government of the Federal Capital does not have the right to organize their own police force. Due to Cafiero's Law 1996 , this is a duty of the Federal Government [7].

Moreover, Argentina, has many types of street level police forces. The majority of polic officers correspond to the Provincial forces, which account for more than 170,000 officers, including the personnel of the PFA, which has street level duties in the City of Buenos Aires . There are also two national organizations of security forces, Gendarmeria Nacional and Prefectura Naval, which jointly account for approximately 36,000 active members. These two more militarized forces have a very different organizational structure. However, the national level includes federal police, national gendarmes, airport and harbor police, naval perfect police, all under civilian supervision [8].

\section{Brazilian Police}

After democracy was restored, the 1988 constitution established a new national structure with Federal Police, 
Federal Highway Police, Federal Railway Police, Military Police, Firefighting Corps, and Civil Police, the latter three bodies being state police forces [8]. The police in Brazil are convened primarily at the state (provincial) level, where they are overseen, staffed, trained, and paid under the jurisdiction of each of the country's 26 state governors plus the governor of the capital district, Brasília [2]. Within each state there are two separate police forces responsible for day-to-day policing. The uniformed Military Police (PM) is responsible for patrol, emergency response. and arrests of crimes in progress; PM officers number 390, 451 across Brazil. The larger states of São Paulo and Rio have 79,812 and 43,774 PMs respectively [9]. The second state police force, the Civil Police (PC), is essentially a plainclothes judicial force that is responsible for investigations and judicial proceedings; nationwide they number 115,960, while São Paulo and Rio's respective $\mathrm{PC}$ force strength stands at 32, 623 and 11,230 [9].

In addition to the two main state police forces, in some large cities Brazil has small municipal police forces that are under the control of local mayors, but their powers are quite limited. The federal government also has a small FBI-style Federal Police force under its control, and this force is responsible for federal investigations in areas such as terrorism, fiscal crimes, forced labour, electoral or political crimes, and drug trafficking, in addition to border control and passport regulation. It has about 10,000 sworn officers [2].

\section{Literature Review}

For the police force to be successful in their mandate as a law enforcement agency, it is important that they operate within an environment that promotes trust between them and the major stakeholders, press, public, and the courts. Goldsmith [10] resolutely brings this point home by examining why trust, in the form of accountability and evenhandedness in the police is and should be the basis of police reforms. The author dissects the issue of why the public mistrusts the police, defines the nature of trust in this context, and explores the relations between the police and the community; carefully observing the complications that exist when trying to institute and sustain trust in the police force. As it concludes, the article focuses on building trust by looking at ways in which distrust can be institutionalized, the challenges that occur in the process of building trust and the importance of trusting the tools in place for building and rebuilding the trust [10].

Distrust in the police is revealed as a hindrance to cooperation with the public. The presence of public trust is thus directly linked to the effectiveness of the police force. This trust is however complicated and fragile, in that it is dependent on many factors that do not necessarily lie within the police force. Some of the factors are to be found in the community with a direct correlation between insecurity, inequality and social disorganization and a lack of trust in the police force. Goldsmith further outlines the relationship between trust and governance by showing how the level of interpersonal trust reflects on government and civil society where the latter plays watchdog to the former. Through the support of combined experiences of societies, Goldsmith identified that a lack of trust in the government is linked to its ineffectiveness. The police are mistrusted by the public mainly because of roles played in the past, structural location in relation to certain groups in society, instances of impunity and partiality in enforcement of laws. To build trust in the police, the following agreeable suggestions are put forth by Goldsmith : promotion of impartial, transparent, and reverent actions in the police force; use of an arbiter in extreme cases of mistrust; image management, to ensure that trust is maintained in case the police are on the offense; rebuilding of trust from the local level and strengthening civil society. In implementing police reforms, the challenges need to be acknowledged, caution needs to be exercised not to overdo things and realistic management of expectations will be required. However, the absence of adequate detail on how to establish a trustworthy police force at individual state or community level and what is the mechanism of accountability is not clearly examined throughout this paper.

Mitchell \& Wood [11] discuss the process and problems that would be associated with a second transition to democracy in Brazil. The authors point out that police behavior is influenced by an institutional framework and culture that is prone to exercising power in a prejudiced manner. In this article, the authors focuses on the large gap between the democratic constitution and law enforcement in Brazil and how this compromises the legitimacy of the government. Even though Brazil is officially a democracy, the change of their political system has done little to eliminate the authoritarian practices of the society, police, and judicial units. The large class gap and lack of law enforcement make crime appealing to those that hope to climb the social ladder and have no other viable way of doing so. Overall, the authors suggest that an elected government alone is not enough for a country to be considered a true democracy. They propose that in Brazil the state institutions and civil society need to be reconstructed, as well as the overall culture, in order to move away from oppression of certain groups.

In as much as the issues of policing reforms are to be localised and addressed with much regard to the history, politics and geographical location within which they occur, Santos [12] puts effort in reminding everyone that the problems and challenges are universal, afterall. The paper makes a point of information by drawing attention to the efforts of world leaders through international conferences and other such forums, knocking their heads together in an attempt to develop and promote new ideas of citizen security that walk hand in hand with new democracy. The obvious failure of public security is a worldwide consensus, with heavy criticism befalling the police culture of unlawful violence, high-handedness and ultimately gross violations of human rights. Analysing the specific problems and possible solutions of policing, Santos further stated that people are 
unable to trust the police to protect them.

In the context of globalization, social issues have definitely morphed into complicated and conflicting subjects, characterized in part by diffuse violence and the absence of collective consciousness or integration that have a negative bearing on the system of criminal justice and other systems as well [12]. On this global scale, the ineffectiveness of secuity agencies has thrown people into perpetual fear of crimes, leading to propositions of alternatives to the police office. These suggestions threaten current power held by the police officers. It is obvious that the world frowns at authoritarian police forces that exhibit violent behaviour and they have expressed willingness to establish different police administrations that embody the principles of democracy such as accountability and arbitration of social conflicts. Participation in the international community has a major downside: it alienates the relevant elements of local communities and their interpersonal relationships to the work of the police, further complicating the security situation. It is therefore important to appreciate the challenges encountered in this transition such as resistance, and focus on bridging the new ideas and concepts.

The idea of a 'community and problem-solving policing' presents itself as a viable strategy in policing and social control since the police are able to tackle local and familiar problems more efficiently with community collaboration [12]. This paper concludes that the government should then ensure it's policies are more inclusive in order to ensure all of society is well-served reducing the need for a forceful police organization required to enforce laws that are oppressive to those already disenfranchised. Furthermore, the police force needs to also play a part in kicking out all corrupt practices with the aim of establishing faith and trust in the instituion.

Another study by Hinton [13] discusses the similarities of policing in Argentina and Brazil where both countries share a common nucleus of problems that have prevented them from establishing police institutions that benefit democracy. It suggests that this problem has been occurring since the early 1980s, when both countries emerged from militaristic dictatorships. The author argued that failure to achieve greater progress in police reform is attributable to other factors such as low levels of training and professionalism, weak controls, and low salaries; which is far more entrenched than bureaucratic resistance to change.

In Argentina and Brazil, while policymakers try to enforce 'new' or 'quick' reforms, they fail to address the existing problems due to the tendency to patterns of patronage, clientelism, unholy alliances and impunity that continue to prevail over checks and balances intrinsic to democratic governance. As a result, the reforms do not work since the politicization of the police and the police institution cannot be a beacon of honesty, service or legalism. It also suggests that when policing is reduced to repressive social control, police start using violence, which, in turn, has led to gross violations to human rights. Hinton explains that the biggest obstacle to public security reform in Brazil is structural, as
Brazil is a profoundly unequal society (p. 8). Therefore, she focuses on how politics interfere with the development and implementation of police reform in Latin America, and focuses on what this means for the future of policing in the region. Overall, Hinton believes that the federal government needs to take a bigger role in leading policy reform and sees police simply as the universal scapegoat for larger, institutional deficits.

Clark [14] reviews the following three structural theories of police violence, specifically in relation to the Sao Paulo area during the last two decades of the 20th century: the reaction-to-crime, the reaction-to-violence, and the threat models. The article begins by discussing the view of the elites that dark-skinned, poor, ill-educated, and rural immigrants are social threats, referring to them as 'dangerous classes'; yet, even though elites tend to put pressure on the police, the author finds that police violence in Sao Paulo is a reaction to crimes such as robbery and assault, regardless of the levels of 'dangerous classes'. The idea is put forth that police violence is linked to short-term changes in social conditions rather than long-term ones.

Ruddell \& Matthew [15] set out to look at the many political, social, and legal factors that shape and determine the deployment of the police in a cross-national sample of 70 developing and developed nations. The findings of this study clearly show the importance of perception in the police strength as determined by the ratio of sworn police force members relative to the general population. The findings of this study were that in some of the countries; especially those in the developing world, there exists a positive correlation between weak political regimes; which are not considered durable, and police strength. The authors attribute this to the fact that that those in charge of the regimes feel the need to use the police strength and numbers to bolster their image and appear to be in control of crime and civil order in their countries. The main point here is that the perception of a regime being strong is important - and it is strengthened by the deployment and use of high police strength. Another related finding was that in those countries where there is a presence of a large or relatively strong black market and where corruption is more rampant, the higher police strength is also usually present, again giving the perception that the authorities are working on solving these issues using the police forces. In the more developed nations, the finding too was that the deployment of higher numbers of police forces and thus the appearance of being "tough on crime" gave the political perception that these countries or parts of these countries were indeed doing a better job of combating crime even when the crime rates did not go down as expected. Paradoxically, despite this show of police might and even when high incarceration rates and the application of capital punishment are implemented such as in the United States, the rates of crime still do not go down significantly. Yet many of these measures are put in place for the purpose of creating the perception that crime and criminality are being tackled.

Ruddell \& Matthew's [15] study has a few weaknesses such as the fact that it is difficult to come up with universal 
definitions of different crimes in such a diverse group of nations, and the differences in context, cultures, and mandates of the police forces in all these countries. Yet another weakness is the lack of accurate data on the operations of non-police actors in crime prevention such as the military and private security operators.

Rosenbaum et al. [16] points out that understanding the nature of public attitudes toward the police is one of the keys to strengthening police community relations. In this regard, this article examines that the public's willingness to cooperate with local police agencies that depend upon their attitudes toward police responses. It is obvious that public attitudes toward the police is a dynamic issue that changes over time; but it has also fluctuated in recent years by the result of vicarious experience via media coverage, government officials' renewed interest in police misconduct and brutality, use of excessive force, racial profiling, and other corrupt behaviors by family members, and neighbors. Therefore, the authors state that public attitudes toward the police should be a multidimensional construct rather than a uni-dimensional concept. This study also suggests that public attitudes toward the police are stereotyped. In the absence of direct contact, Whites are inclined to have a positive prejudice toward the police, whereas minorities tend to hold a negative stereotype.

Rosenbaum et al. [16] appreciates how challenging it is to develop the intervention for strengthening police-community relations without identifying the root causes of negative public attitudes toward the police. However, without public support, the police are essentially limited in their ability to build crime prevention partnerships, maintain order, alleviate neighborhood problems, and gain the support for budget requests.

Dowler \& Zawilski [17] looked at the impact of media consumption on viewers' attitudes and perceptions about police misconduct and discrimination. The aim of the study was to see what impacts the various portrayals (both negative and positive) of the police in the public media have on the public. The findings of this study revealed that heavy consumers of network news or those who spent a lot of time watching and listening to the media were more likely to have the perception that police misconduct was a frequent occurrence. Since most of the reported instances of police misconduct involved non-white persons, the perception of the non-white high consumers of news media was that the police misconduct is always targeted at them and unfairly favored the white population. Thus, the media was responsible for the perception of not only high incidence of misconduct but also that it was often against minority persons even when that was not the case. Another finding of this study was that frequent viewing and listening of police and courtroom dramas in the media led the consumers to believe that the wealthy always or often received preferential treatment from the police. Yet those who viewed crime solving shows - where the police always got the right culprit and the ones who were on the right side of the law were always vindicated - did not think the wealthy received better treatment from the police.

Among the viewers of police reality shows, where the common themes appear to be the use of aggressive police techniques to counter resilient and resourceful criminals, the perception built among the white viewers was that stronger police measures were required to counter crime. On the other hand the non-white consumers of these media programs felt that they were always placed in the position of the crime perpetrator. Yet again, perceptions were created based on who was watching the program.

This article, like the previous one, shows how in the area of crime, crime prevention and crime detection, perception, whether based on true or realistic events or not, plays a large role in determining people's attitudes towards law enforcement.

According to Ruddell \& Thomas [15] police distribution cross-nationally, is heavily dependent on social, legal and political factors. After investigating 70 developed and developing countries, this article confirms the existence of an inherent relationship between politics; state formation, government robustness, corruption and the strength of the police worldwide. Based on this discovery, important questions are posed on whether the deployment of police is in an effort to strengthen despotic administrations or is it in response to social problems. By drawing comparisons between nations, edifying patterns and themes emerge to inform new perceptions that contribute to the formation of social control theories.

Looking at police strength as a ratio of sworn law enforcement personnel per residents in the population to make comparisons cross-nationally, the article was able to map out recurring patterns of police strength with respect to politics [15]. Findings reveal that weak governments rely greatly on the police to reinforce their unpopular reign, diminishing the expected but false notion that police deployment is dependent on levels of crime. In conclusion Ruddell \& Thomas recommend prioritisation of the understanding the relationships between police distribution and social, economic, political factors in order to influence how the police are deployed.

\section{Discussion}

This paper argues that the authoritarian practices of policing erode current democracies in Argentina and Brazil. Thus, concentrating on Sao Paulo-Brazil, critically looking at the issue of police impunity it is easy to identify patterns of police abuse through the analysis of famous kidnappings cases by Caldeira [18]. Through the field observations, interviews, and available statistical evidence there exists a paradox that the support of police violence co-exists with negative thoughts about the police force and their victimization of the working-class. From the prism of fieldwork completed between 2001 and 2002, Caldeira explores the challenges encountered in the police force while introducing democratic reforms. Worth noting are the 
prevalent themes of: police violence, persecution of marginalized communities and a deep-seated cynicism associated with the judicial system; stemming from an extended history of abuse of the public's rights.

In Sao Paulo, police abuse, corruption, resistance to democratic reforms, disregard for people's rights and extra-judicial killings with alarming numbers of people dying in the hands of the police is, sadly, the norm. Through detailed narratives of kidnapping incidences; a rising crime in the city, a conflict that exists between the civil police and military police: the two arms of the police, comes to light. The police force is seen by the general public as trigger-happy and is accused of being all too ready to use lethal force, eager to overstep their mandate as provided for in the law and believed to be corruptible.

Since 1999 at least $10 \%$ of the murders in that year are allocated to the police force with a hefty chunk of the blame falling under the military police [18]. According to information from the office of the police ombudsman on charges leveled against defiant officers, most of them were accused of extortion, abuse of authority and homicides, in that order.

Despite the political will and the establishment of an office of police ombudsman to temper the police forces, people, communities and especially the working class are still harrassed both by criminals and the people who should be protecting them. This, has without a doubt heightened the state of fear, level of mistrust and disrespect among the citizenry of Sao Paulo, a situation that is compounded and made more challenging to address due to an extendend history of police injustices.

The challenge in Sao Paulo; with regards to penetrating the police force with the aim to introduce and implement democratic reforms, is enormous and will need collaboration from all quarters: the community, the government and most importanly from the police officers. This state of affairs will require that the police view the community as partners.

The author concludes that public security and policing are two of the most problematic issues in Brazil today. Although some parts of the Brazilian society have been effectively democratized, other parts - such as civil rights, the justice system, and public security - continue to be evaluated based on privilege and police violence, therefore, continues to be considered an acceptable way to deal with crime.

Using the subject of drug law enforcement to show selective treatment by police in San Francisco, Lynch et al. [19] are able to show in depth the issue of police impartiality and structural location with regards to race and geography. The reality of San Francisco is that they have the highest rates in racial dispropornality on the subject of drug arrest. Despite being a 'progressive' city, there is a sharp contrast of San Francisco's liberal persona; characterized by numerous movements for social justice, juxtaposed with its history of oppresive policies against the disenfranchised citizenry[19]. This policing quagmire of selective enforcement of the drug law is linked both directly and indirectly to the local politics of the city that influence the structures of the police force, resulting in racial discrimination.

The subliminal messages communicated by such disparities lay bare the inherent connection of a just or unjust police system with the government, the locality and history of community-police ralations. The specific attributes of a place play a significant role in substantiating patterns of drug arrests, disqualifies the notion that aggreagate data fairly represents the extent of the problem. With the use of a few maps, the paper affirms the coorelation between incidents of narcotics and districts with large black population [19]. By singling out jurisdictions, case studies are best able to show the precise circumstances under which selective drug law enforcement takes place. These circumstances thus reveal the absolute interaction of politics, economics and culture within which policing takes place, offering better understanding of historic and cultural influences that give rise to disproportionate drug arrest results.

In order to make fair comparisons with other urban areas such as: New York, Cleveland and Seattle, the paper employs 'cities' as a critical criteria, measured by demographic profiles of residents, population densities, growth trends and socio-geographic factors. This exercise impresses the fact that local policing differs substantially in every city and responds differently to 'problem areas'. With this backdrop, a fair and impartial San Francisco police force would only be achieved by acknowledging the connection between location, race and drug law enforcement; analyzing drug arrests by individual jurisdictions; then fashioning and implementing contemporary policing strategies along these realities.

What is the bee in the bonnet of many young men in poor black neighborhoods? According to ethnographic observations by Goffman [20], the answer to that question is unfortunately but expectedly, 'avoiding jail'. As the number of people incarcerated in the U.S has risen over the years, one cannot ignore the fact that uneducated or little educated Black men form the bulk of the group. From these and other scientific observations of policing and the poor; cultures and customs, the author flips the coin to deliberates over the repercussions of supervision and policing on the targeted individuals, communities and society in general.

Through a variety of stories, locations and relations; hospitals, places of employment, courts, police, friends and families, one is able to gather how they are used by authorities to make arrests and the strategies employed by those wanted for arrest to evade prison. An effective system of justice cannot be measured by the number of indivuduals sentenced to serve a jail term. In contrast to fostering trust, the justice system in poor communities promote suspicion and fear where young men live like they are on the run in perpetual fear of being arrested [20].

Many cities in Latin America, have in the recent past earned themselves the infamous reputation of 'murder capital of the world' characterised by so much criminal violence and a large number of homicide cases [21]. This is despite the impressive reforms that have taken place in the 
systems of justice and the police institutions in those cities, following the restoration of democracy. Ungar [21] gives details of the manner in which the reforms were implemented amidst the chaos that was going on at the time; expanding criminal organizations and a rising rate of crime. The reforms tackled the issue of providing the police with professional assistance, effecting legal changes, community policing, structuring the organizations and developing control mechanisms. Despite the efforts, the reforms continue to fail in achieving citizen security.

The law enforcement reforms were fraught with challenges which are attributed to applying a practice-oriented method to policing as opposed to a problem-oriented one. The later approach is a sensible recommendation because it departs from the status quo procedures that were used during the totalitarian period; and is essential in creating legitimate governance and democracy as it solves the security predicament. Drawing the link between democracy and security highlights the delicate balance between the two: insecurity is a danger to democracy.

Hinton [13] draws a number of similiarities between States in Latin America focusing on the two most powerful nations: Brazil and Argentina, with respect to their shared history of repressive rule under the military; more than twenty years ago. Using this background one can argue that irrespective of the differences between Brazil and Argentina in present times, their shared history still defines the heart of the problems they face in the policing arena. To address the question of why the two countries have been unable to establish an effective police/ justice system, one must explore the causation relationship between the States' excessive police politicization during the totalitarian era and the factors that have been plaguing police governance from the time electoral democracy was reinstated.

After independently investigating four key areas: police governance, historical background, resistance to reforms by the police and horizontal accountability, the findings point to the preservation of an unprofessional and anti-reformist police force as the reason why Brazil and Argentina are far from achieving democratic policing [13]. A weak civil society whose impact on sustainable change is only felt sporadically, further compounds the troubles of public security and police governance in Latin America. This backdrop, when extrapolated resounds with the larger Latin America.

In the city of Sao Paulo, Brazil, the Civil Police struggle with democratic change, thirty years after democratic rule came into effect. They remain repressive, corrupt and continue to practice extrajudicial procedures resisting democratic pressure to be transparent and accountable. lnvestigatating why they have not made the expected progress Willis [22] invites one to look at the 3 categories of authority: criminal, institutional and public, yielded by the civil police and how the authorities shape how they exercise their mandate. These three authorities are incompatible and the antagonistic nature of the authorities bring into play multiple manners of resistance that make the police unaccountable.

As an organization, the police is not resitant to democratic changes, this reality is however, made complex by the structures of authority and power that ultimately affect their decision-making processes. The police is not entirely opposed to democracy, but their institutional constraints such as the deficiency in resources facilitates tacit corruption from the powers that be. The challenges involved in police's interaction with certain criminal elements, have in certain instances seen police officers colluding with the criminals. This is especially so in instances where the police face great threat that requires them to protect themselves and their families.

'Talk the talk but not walk the walk' is how Clifford [23] describes democracy in government rule. To reinstate true democracy back into this state of affairs, it is recommended that the institutions should take stock of the success and failures of policing; improve the good and fix the bad, then welcome and engage the participation of the general public on the high level discussions. They should also cushion the police by spreading the responsibilities of policing across the board: the justice system and the arms responsible for preventing crime, they should be trained on policing and should all shoulder the burden of a non-performing policing institution. They should losely monitor the growth of a private security so as to even-out the playing field for those who cannot afford their services and ultimately to preserve the indispensible role of public security in a democracy. The management of the institution should not be left to the police alone, but should involve the public and more importantly consult with management experts who can give their professional input in the design and short-term to long-term activities of the institution.

The police should endeavor to practice an open-door relationship with the media; centred on objectivity, to effectively manage their public relations, allowing for public participation. This initiative would go a long way in repairing the enstranged relationship between the police and the public. Delinking the police from prosecutions and letting legal prosecutors pursue prosecutions will allow and encourage the police to focus on their primary roles of detecting crime and collecting evidence, thereby, encouraging democracy to thrive while guarding their public relations. Additionally, in anticipation of a more active public, the police should heighten their skills in the management of public agitation in the form of demonstrations and riots. Lastly, the police force should endeavor, under all cisrcumstances, to be a reliable round-the-clock social service that can be depended upon by the public [23].

Democratizing policing extends beyond 'Subjecting the police to the judiciary'. Posing questions such as 'What kind of power is invloved in policing?' and 'Can police discretion and state force be given democratic uses?' Seri [24] gathers narratives from police officers across the board with an aim of re-examining the power held by the police. Sharing 
narratives and a new understanding of law; both written and unwritten, will influence the usage of discretionary power. Narratives are powerful tools that help shape situations and perceptions, infering that the narratives will restore the intended notions of democratic policing and will primarily infuse democracy on power that is unregulated by written laws. Police discretion falls squarely under this category, making it a priority to investigate police narratives and the impact they have on matters of policing. This view, departs from the status quo in efforts to improve democracy within policing and introduces a fresh outlook on the issue. "We cannot eliminate discretion, but we can democratize its exercise," [24].

According to the report of Amnesty International [25], there has been a sharp rise in violent crime, due in large part to frustration with the state of Brazilian society, and to the inability of the government to improve living conditions. At the root of this violence is the lack of a functioning justice system and law enforcement structure. Bribery and corruption also plague the system and delegitimize the police; people believe that government officials accept money as an exchange for silence. The high levels of crime in many parts of Brazil promote police violence because the police are not held accountable for their violent actions, if the actions are deemed appropriate in order to control crime. Many citizens, including those in the marginalized groups, believe that police officers should not have to obey the law in order to uphold it.

Another report by the Amnesty International [26] lays out the following flaws in the Brazilian criminal justice system: lack of independent bodies; lack of independent and properly resourced forensic investigation units; limited protection for victims or witnesses of human rights violations; limited access to justice. State and federal governments have ignored the area of public security policy due to short-term political interests, corrupt practices, and a lack of civic duty. The report concludes that the government must take part in reducing police killings by making sure that investigations take place for every allegation, by making the findings public, and by making sure fair trials are conducted.

In Latin America, there exists a situation where, democratic policing is but an ambitious aspiration while the policing reality continues to be a non-democratic one. This disparitybetween totalitarian and democratic policing is characterized by accountability of the police force to government and criminals but not to law. There is also the complex matter of the police becoming less totalitarian without necessarily becoming more democratic. Prado, Trebilcock, \& Hartford [27] categorize the deviations from democracy into 3: the autocratic police force, criminal police and autakic police. The autocratic police is manipulated by an oppressive regime, criminal police is controlled by criminals while autarkic police is rogue and unaccountable.

With regards to the above discussion, we would say even as the threat of military rule has diminished in many countries in Latin America but due to more robust forms of civil-military control, the insidious effects of authoritarian historical legacies remain. Therefore the external and internal police reforms carried out in Latin America have failed to achieve a democratic police because they try to solve visible problems in the system while ignoring inherent inefficiencies in the institutions, what the authors call a principal-agent problem. In this equation the police is turned into the criminal while the criminals become the principals. The recommended solution to this problem is to make law into an effective principal; where the police force follow the law as they execute their mandate and remain accountable to the law.

\section{Conclusions}

To tackles the issue of reducing the public fear of crime in Latin Ameica and how the policy makers can achieve this is an excellent area for further research. By contrasting the efficacy of community-based policing strategies and that of 'zero tolerance' in Brazil, Argentina and other countries in Latin America, Dammert \& Malone [28] arrived at the conclusion that insecurities that revolve around political, economical and social aspects of citizens determine their fear of crime on a micro-level. On a macro-level, with respect to public insecurity, community-based strategies in fighting crime yield lower levels of public fear of crime.

The fear of crime in Argentina for instance, has facilitated a "tough on crime" mentality among the leadership which has in turn enabled extrajudial practices in dealing with crime. The role of community-participation in policing strategies is therefore imperative and cannot be understated as it leads to lower levels of fear of crime in the general public, consequently allowing for the successful implementation of policing reforms that are long over-due.

The role of civil society and research bodies in democratizing policing also offers an excellent opportunity for further research. NGOs and other community organizations are well placed to eloquently express the anxieties of the public concerning police abuse and crimes. Research organizations and scholars can pour their advanced knowledge and technical skills to gather and investigate data on crime that would be of immense help to the police. Since information on police reforms are hard to come by especially in Latin America, researchers can gather, document and archive past experiences in the process of police reforms, data that would come in handy in the development of future reforms.

\section{REFERENCES}

[1] Ward, H. H. Police Reform in Latin America: Observations and Recommendations. Woodrow Wilson Center Update on the Americas, No.5, 1-4, 2002.

[2] Hinton, M. S. Police and state reform in Brazil: Bad apple or rotten barrel? In Hinton, M., \& Newburn. T (Eds.) Policing Developing Democracies. (pp 213-233). Abingdon: 
Routledge, 2008.

[3] Rawlings, P. The Idea of Policing: A History. An International Journal of Research and Policy, Vol.5, No.2, 129-149, 1995.

[4] Jones, T., T, Newburn. \& D. Smith. policing and the idea of democracy, British journal of Criminology, Vol.36, No.2, 182-98, 1996.

[5] Das, Dilip. K. Challenges of policing democracies: A World perspective, Policing. An international journal of police strategies \& Management, Vol. 20, No.4, 609-630, 1997.

[6] Marenin, Otein. The goal of democracy in international police assistance programs, Policing. An international journal of police strategies \& Management, Vol. 21, No.1,159-177, 1998.

[7] Boruchowicz, C., \& Wagner, R. Why do Argentines trust less their Police than Chileans do? Institutional decay over the 20th century, 2011. Online available fromhttp://sites.tufts.ed $\mathrm{u}$

[8] Johnson, S., Mendelson, J. Forman \& Bliss, K. (Police Reform in Latin America implications for U S. policy. The Center for Strategic and International Studies (CSIS), Washington, DC, 2012.

[9] Secretaria Nacional de Segurança Pública (SENASP) Relatório descritivo (perfil das organizações de segurança pública. Brasilia, SENASP, 2007.

[10] Goldsmith, A. Police Reform and The Problem of Trust. Theoretical Criminology, Vol.9, No.4, 443-470, 2005.

[11] Mitchell, Michael J., and Charles H. Wood. "Ironies of Citizenship: Skin Color, Police Brutality, and the Challenge to Democracy in Brazil." Social Forces, Vol.77, No.3, 1001-1020, 1999.

[12] Santos, J. V. The World Police Crisis and The Construction of Democratic Policing. International Review of Sociology, Vol.14, No.1, 89-106, 2004.

[13] Hinton, M. S. A Distant Reality: Democratic Policing in Argentina and Brazil. Criminal Justice, Vol.5, No.1, 75-100, 2005

[14] Clark, Timothy W. "Structural Predictors of Brazilian Police Violence.” Deviant Behavior, Vol.29, No.2, 85-110, 2008.

[15] Ruddell, R., \& Thomas, M. O. Does Politics Matter? Cross-National Correlates of Police Strength. Policing: An International Journal of Police Strategies and Management,
Vol.32, No.4, 654-674, 2009.

[16] Rosenbaum, D. P., Schuck, A. M., Costello, S. K., Hawkins, D. F., \& Ring, M. K. Attitudes Toward The Police: The effects of Direct and Vicarious Experience. Police Quartely, No. 8, 343-365, 2005.

[17] Dowler. K. and Zawilski, V. Public perceptions of police misconduct and discrimination: Examining the impact of media consumption, Jounal of Criminal justics, Vol. 35, 195-203, 2007.

[18] Caldeira, T. The paradox of Police Violence in Democratic Brazil. Ethnography, Vol.3, No.3, 235-263, 2002.

[19] Lynch, M., Omori, M., Rousell, A., \& Valasik, M. Policing the 'Progressive' Cit: The Racialized Geography of Drug Law Enforcement. Theoretical Criminolgy, Vol.17, No.3, 335-357, 2013.

[20] Goffman, A. On the Run: Wanted Men in Philadelphia Ghetto. American Sociological Review, Vol.74, No.3, 339-357, 2009.

[21] Ungar, M. Policing Democracy: Overcoming Obstacles to Citizen Security in Latin America. In J. M. Cruz, Elections, Contestation, and Democracy, Vol.11, 918-919, 2011.

[22] Willis, G. D. Antagonistic Authorities and The Civil Police in Sao Paulo, Brazil. Latin American Research Review, Vol.49, No.1, 3-22, 2014.

[23] Clifford, W. Policing A Democracy. Police Studies, Vol.6, No.2, 3-21, 1983.

[24] Seri, G. S. Policing and Democracy: The Influence of Narratives on Police Discretion. Michigan, U.S.A: ProQuest Information and Learning Company, 2005.

[25] Amnesty International. Brazil: Submission to the UN Universal Periodic Review: First Session of the UPR Working Group, 2008. Online available from http://www.amnesty.org

[26] Amnesty International. Brazil: 'They Came in Shooting': Policing Socially Excluded Communities: Facts and Figures and Case Studies, 2005. Online available from http://www.amnesty.org

[27] Prado, M. M., Trebilcock, M., \& Hartford, P. Police Reform in Violent Democracies in Latin America, 2012. Online available from Yale Law School: http://www.law.yale.edu

[28] Dammert, L., \& Malone, M. F. Does It Take a Village? Policing Strategies and Fear of Crime in Latin America. Latin American Politics and Society, Vol.48, No.4, 27-51, 2006. 